\title{
Validation of body condition score system in Holstein $x$ Zebu cows via ultrasound method during the transition period and early lactation
}

\section{Validação por ultrassonografia da condição corporal em vacas mestiças Holandês $x$ Zebu durante o período de transição e fase inicial de lactação}

\author{
Narjara Rodrigues Gentil1*; Anselmo Domingos Ferreira Santos²; \\ Mikaele Alexandre Pereira ${ }^{1}$; Mariana Santos Lima ${ }^{1}$; José Cláudio Torres \\ Guimarães ${ }^{1}$; Ludmila Couto Gomes ${ }^{3}$; Francielle da Conceição Dantas ${ }^{4}$; \\ Veronaldo Souza de Oliveiras
}

\begin{abstract}
This study aims to validate, by means of subcutaneous rump fat thickness (RFT), the suitability of the visual evaluation of body condition score (BCS) to indicate the body condition of crossbred dairy cows (Holstein $\mathrm{x}$ Zebu) during the transition period and early lactation. Animals were selected according to lactation period and distributed into three groups: PP ( 0 to 4 weeks antepartum; $n=30), L 4$ ( 0 to 4 weeks postpartum; $n=15)$, and $\mathrm{L}+5$ (5 to 14 weeks postpartum; $n=63$ ). The relationship among RFT, BCS, and body weight (BW) was investigated using correlation and regression analyses. The variables BCS, $\mathrm{RFT}$, and BW were different among the three groups $(\mathrm{P}<0.05)$. The correlations between $\mathrm{BCS}$ and RFT were higher in groups $\mathrm{PP}$ and $\mathrm{L}+5(\mathrm{r}=0.78$ and $\mathrm{r}=0.71$ respectively). However, the $\mathrm{L} 4$ group showed a weak correlation $(\mathrm{r}=-0.04)$. The regression models were able to explain how much RFT varies because of changes in BCS, with coefficients of determination equal to 0.61 for PP and 0.51 for $\mathrm{L}+5$ group. In conclusion, BCS can be considered a good predictor of RFT for crossbred Holstein $\mathrm{x}$ Zebu cows in antepartum and postpartum for over 5 weeks of lactation.
\end{abstract}

Key words: Antepartum. Postpartum. Energy reserve. Dairy cows.

\section{Resumo}

Objetivou-se verificar por meio da espessura de gordura subcutânea na garupa (EGG) se o método de avaliação visual de escore de condição corporal (ECC) é apropriado para indicar a condição corporal de vacas leiteiras mestiças Holandês x Zebu no período de transição e fase inicial de lactação. Os animais foram selecionados de acordo com estágio de lactação e foram divididos em três grupos: grupo PP (4

1 Discentes, Programa de Pós-Graduação em Zootecnia. PROZOOTEC, Universidade Federal de Sergipe, UFS, São Cristóvão, SE, Brasil. E-mail: narjararodrigues15@gmail.com; mikaeleapereira@gmail.com; ma.ri.lima@hotmail.com; claudioveter@ hotmail.com

2 Prof., Departamento de Medicina Veterinária, UFS, São Cristóvão, SE, Brasil. E-mail: anselmodfsantos@yahoo.com.br

3 Pós-Doutoranda, Programa de Pós-graduação em Zootecnia, PROZOOTEC, UFS, São Cristóvão, SE, Brasil. E-mail: ludmilacoutogomes@gmail.com

4 Discente, Curso de Graduação em Zootecnia, UFS, São Cristóvão, SE, Brasil. E-mail: franciellezootecnia2015@hotmail.com

5 Prof., Departamento de Zootecnia, UFS, São Cristóvão, SE, Brasil. E-mail: veronaldo@terra.com.br

Author for correspondence 
a 0 semanapré-parto; $\mathrm{n}=30$ ); grupo L4 ( 0 a 4 semanas pós-parto; $\mathrm{n}=15$ ); grupo $\mathrm{L}+5$ ( 5 a 14 semanas pós-parto; $\mathrm{n}=63)$. As variáveis $\mathrm{ECC}, \mathrm{EGG}$ e $\mathrm{BW}$ variaram entre os três grupos $(\mathrm{P}<0,05)$. As correlações entre ECC e EGG foram maiores nos grupos PP e L+5, com $\mathrm{r}^{2}=0,78$ e $\mathrm{r}^{2}=0,71$, respectivamente. O grupo L4 apresentou fraca correlação com $r=-0,04$. Os modelos de regressão foram capazes de explicar o quanto da variação de EGG é devido à variação de ECC, com resultados de coeficientes de determinação igual a 0,61 para o grupo PP e 0,51 para o grupo L+5. Em conclusão, para os animais do pré-parto e do pós-parto com mais de cinco semanas de lactação o ECC pode ser considerado um bom preditor da EGG.

Palavras-chave: Pré-parto. Pós-parto. Reserva de energia. Vacas leiteiras.

\section{Introduction}

Body condition scoring (BCS) is widely used in cattle to assess nutritional status and changes in energy reserves (SHELDON et al., 2006). In spite of this, no studies have evaluated whether the BCS technique elaborated by Edmonson et al. (1989) is suitable for estimating the body condition of crossbred Holstein x Zebu cows.

The association between BCS and ultrasound measurements of subcutaneous fat thickness can be performed to evaluate the energy status of dairy cows (HUSSEIN et al., 2013), thereby increasing the accuracy in visual assessment of body condition.

The transition period in dairy cows is an interval of three weeks before and after calving (GRUMMER, 1995). Physiological, hormonal, metabolic, and anatomical changes in this phase are accompanied by a reduction in the animal intake and an increase in energy demands, which is due to the nutrient needs for the pregnant uterus and mammary glands (GOFF; HORST, 1997; HUZZEY et al., 2007). Consequently, dairy cows mobilize body reserves to overcome this energy deficit. Therefore, the assessment of body condition of these animals during the transition period is important because the intense lipolysis can provoke metabolic disorders as ketosis and hypoglycemia (MULLIGAN et al., 2006).

Although some studies have been carried out on BCS, RFT, and body weight (BW) recently, the relationship among these characteristics has not been assessed for Holstein $x$ Zebu cows (H-Z). Thus, this study aims to validate, by means of subcutaneous rump fat thickness (RFT), the suitability of the visual evaluation of body condition score (BCS) to indicate the body condition of crossbred dairy cows (Holstein $\mathrm{x}$ Zebu) during the transition period and early lactation.

\section{Material and Methods}

This study was approved by the Ethics Committee for Animal Research (CEPAP), Federal University of Sergipe (Protocol: 10/15). The experiment was conducted in six dairy farms located in Alto and Baixo Sertão, and Baixo São Francisco regions across Southern Sergipe state, in Brazil. The average maximum and minimum temperatures were $26.5 \pm 1$ ${ }^{\circ} \mathrm{C}$ and $22.2 \pm 1.12{ }^{\circ} \mathrm{C}$, respectively; and the average rainfall was of $1120.3 \pm 276.45 \mathrm{~mm}$. (CLIMATEDATA.ORG, 2016). All the evaluated farms had a similar semi-intensive management system, and the animals were fed according to milk production standards (NRC, 2001). The diets were composed of corn silage, ground corn, soybean meal, and mineral supplement; nonetheless, in this case, each farm had its own nutritional management, with diets being formulated according to the availability of each ingredient.

Data were gathered from 108 crossbred dairy cows (Holstein x Zebu) with a daily milk yield of $15.4 \pm 9.5 \mathrm{~kg}$. Multiparous cows were randomly selected and classified into three different groups according to their stages of lactation: PP ( 0 to 4 weeks antepartum; $\mathrm{n}=30$ ), L4 (0 to 4 weeks postpartum; $n=15), L+5$ (5 to 14 weeks postpartum; $n=63$ ). 
The same trained person performed all visual evaluations. Routine data collection always started after the first milking when animals were restrained to enable the evaluator a full view of the animal body. None of the farms had scales available for the weighing of animals, so the body weight (BW) was estimated using a weighing tape for dairy cattle.

Body condition score (BCS) was evaluated according to the method proposed by Wildman et al. (1982) and validated by Edmonson et al. (1989). This approach is based on a visual and tactile appraisal of animal body reserves in some parts such as transverse process, sacral ligament, lateral hip joint, ileus, and ischium. In this way, the cows were classified on a scale ranging from 1 (thin) to 5 (extremely fat), with quarter-point increments (0.25).

Subcutaneous rump fat thickness (RFT) was measured as described by Schröder and Staufenbiel (2006), with a portable ultrasound device (Pie Medical) coupled to a 6-MHz linear transducer. The measurements were performed with the transducer positioned vertically to an imaginary line between the ilium and ischium bone ends. The skin contact with the transducer was made using colorless conductive gel, suitable for ultrasounds. Once an image that best characterized RFT was obtained, it was frozen and stored for later measurement by IMAGEJ software (US National Institutes of Health). This measure includes the distance (mm) between the skin and the deep fascia, located above the gluteus medius muscle. The animal hindquarter was chosen for fat thickness evaluations because it allows high repeatability and is a region suitable for subcutaneous fat measurements according to Stouffer and Cross (1985). In addition, it is a region with greater sensitivity to body condition variations (SCHWAGER-SUTER et al., 2000), as it has a faster mobilization when compared to the dorsal region.
The relationships among visual body condition score (BCS), body weight (BW), and subcutaneous rump fat thickness (RFT) were established by statistical analyses at 5\% probability, using SAS software, version 9.1 (SAS, 2002). The experiment was carried out in a completely randomized design (CRD) for each lactation period (PP, L4, and L + 5). The statistical assumptions of homogeneity of variances and residue normality were verified with the aid of the procedure PROC UNIVARIATE of SAS. Analysis of variance (ANOVA) was performed with PROC MIXED for each variable (BW, BCS, and RFT) to check for statistical differences ( $p$ $<0.05)$ for the three groups. From these results, a polynomial regression was made to obtain the best effect for each of the analyzed variables. After choosing the best model (by the effect p-value), regression analysis was then performed with PROC REG of SAS.

A general regression was carried out considering all animals regardless lactation period, in which RFT used as a dependent and BCS as an independent variable. The Pearson correlation procedure (PROC CORR) was also used to check the relationship among variables (BCS, RFT, and BW), taking into account the total number of observations within each group for BCS and RFT.

\section{Results and Discussion}

Significant differences were found for the variables BW, RFT, and BCS in each stage of lactation (Table 1). BCS ranged from 1.75 to 4.00 , with the highest mean of 2.81 for cows from group L4 ( 0 to 4 weeks postpartum), and the lowest of 2.50 for group L+5 (5 to 14 weeks postpartum). Yet RFT varied between $4.05 \mathrm{~mm}$ to $25.6 \mathrm{~mm}$, with the highest value of $9.62 \mathrm{~mm}$ for PP group (0 to 4 weeks antepartum), and the lowest of $5.82 \mathrm{~mm}$ for L+5 group. 
Table 1. Body weight, rump subcutaneous fat thickness on the back and body condition score of Dutch $\mathrm{x}$ Zebu crossbred cows during the transition period and early stages of lactation.

\begin{tabular}{|c|c|c|c|c|c|c|c|}
\hline \multirow{3}{*}{ Variable } & \multicolumn{6}{|c|}{ Physiologicalstage* } & \multirow{3}{*}{ P-value } \\
\hline & \multicolumn{2}{|c|}{ PP } & \multicolumn{2}{|c|}{ L4 } & \multicolumn{2}{|c|}{$\mathrm{L}+5$} & \\
\hline & Average & SEM & Average & SEM & Average & SEM & \\
\hline Body weight (kg) & 507,50 & 11,15 & 473,34 & 11,43 & 488,54 & 9,39 & 0,02 \\
\hline Rump subcutaneous fat thickness(mm) & 9,62 & 0,07 & 8,51 & 0,07 & 5,82 & 0,06 & 0,03 \\
\hline Body condition score & 2,81 & 0,08 & 2,64 & 0,08 & 2,50 & 0,06 & 0,01 \\
\hline
\end{tabular}

* Physiological stage: PP (4 to 0 weeks antepartum); L4 (0 to 4 weeks postpartum); L + 5 (5-14 weeks postpartum).

**SEM: standard error of the mean.

Similar results were found by Hussein et al. (2013), who observed the highest means of BCS (3.5) and RFT (24.4 mm) for cows from the first to third weeks before calving, and of BCS (2.3) and RFT $(13.7 \mathrm{~mm})$ for postpartum cows. Overall, they observed adipose tissue losses similar to those in this study. Such differences in BCS and RFT can be justified by adipose tissue mobilization to attend the energy demand for milk yield. As it is a regular physiological process in all mammals, all cows should be expected to mobilize body fat in early lactation (NRC, 2001).

BW ranged from 332 to $709 \mathrm{~kg}$, with the lowest values found in cows from group L4, while the highest ones for animals from group PP. Weber et al. (2013) found a similar result when assessing Holstein cows during the eight weeks before calving until nine weeks postpartum. These authors observed a significant decrease in BW after calving until the fifth week of lactation, and then remaining constant until the end of the study, resulting in a 0.75 -point loss in body condition. The distinct behavior of BW in relation to the other variables might be because of it is easily influenced by several factors such as gastrointestinal tract contents and uterine weight changes (SCHRÖDER; STAUFENBIEL, 2006). As food intake increases, the gastrointestinal contents also raise (gut filling). The gut filling rate in dairy cows is equivalent to nearly $15 \% \mathrm{BW}$ (NRC, 2001). Chilliard et al. (1991) suggested that for each kilogram increase in dry matter intake (DMI) it is necessary a gut-filling rate of 4 kilograms. Nonetheless, BW changes may not reflect the real changes in tissue energy reserves of dairy cows.

Table 2 shows curvilinear variations in both BW and RFT, and according to the regression equations, the lowest values were found at 42 and 109 days after calving, respectively.

Table 2. Regression equations as a function of time for the body weight $(\mathrm{kg})$, rump subcutaneous fat thickness on the back (mm) and body condition score of Dutch x Zebu crossbred cows during the transition period and early stages of lactation.

\begin{tabular}{llll}
\hline Variable & Regression equation & $\mathrm{R}^{2}$ & $\mathrm{P}$-value \\
\hline Body weight & $\mathrm{y}=454.35278-1.47864 \mathrm{x}+0.01741 \mathrm{x}^{2}$ & 0,15 & $<0,01$ \\
Rump subcutaneous fat thickness & $\mathrm{y}=0.88412-0.00556 \mathrm{x}+0.00002545 \mathrm{x}^{2}$ & 0,23 & $<0,01$ \\
Body condition score & $\mathrm{Y}=2.78325-0.00259 \mathrm{x}$ & 0,08 & $<0,01$ \\
\hline
\end{tabular}

$\mathrm{R}^{2}$ : coefficient of determination. 
The cows of group L4 showed an average milk production of $10.3 \pm 4.3 \mathrm{~kg} \mathrm{day}^{-1}$ (corrected to $4 \%$ fat), while those of group $\mathrm{L}+5$ produced $14.6 \pm$ $10.0 \mathrm{~kg}$ day $^{-1}$ on average. Physiologically, BW, RFT, and, BCS changes among the evaluated periods are already expected for lactating cows. Over transition period and early lactation, these animals undergo changes in their body composition. These changes corresponded to a decrease in BW, RFT, and BCS as a way to meet the common high demands for energy during this phase, regardless of the productivity level of animals. Notwithstanding, such bodyreserve dynamics is more intense in productive animals.

Despite the significant differences in BW, BCS, and RFT among the studies groups $(p<0.05)$, the low coefficients of determination $\left(\mathrm{R}^{2}\right)$ show that the estimated do not fit to the observed data, probably due to heterogeneity in the observations.

In the study of Vargas Junior (2003), a correlation between BCS and RFT equal to 0.50 was observed for Nellore cows. We also found similar results, with moderate correlations $(r=0.57)$ between BCS and
RFT when all the animals in the experiment were considered, regardless of the phase. Conversely, BW presented a weak correlation with BCS $(\mathrm{r}=$ $0.28)$, and moderate with RFT $(r=0.38)$. Likewise, Ayres et al. (2009) assessed correlations among BW, BCS, and RFT in Zebu cows from the final third of gestation and 16 weeks postpartum by means of ultrasonography. These authors found a moderate correlation between BW and BCS $(r=0.37)$, and a strong one between BW and RFT $(r=0.50)$. In our study, the low correlation between BW and the other variables (RFT and BCS) can be explained because this variable is a poor indicator of energy reserves in cows during the transition period (NRC, 2001).

Table 3 shows the correlation analysis between RFT and BCS for each group. The largest correlation coefficients were found for cows of groups PP and $\mathrm{L}+5$; while for group $\mathrm{L} 4$, it was null and inverse. Possibly, these results are due to the small number of animals representing this group, as the evaluations were conducted in farms with a few number of females between 0 to 4 weeks postpartum.

Table 3. Pearson correlation coefficients (r) for rump subcutaneous fat thickness on the back and body condition score of Dutch $\mathrm{x}$ Zebu crossbred cows during the transition period and early stages of lactation.

\begin{tabular}{llll}
\hline Physiological stage $*$ & Number & r & P-value \\
\hline PP & 33 & 0.78 & $<0.01$ \\
L4 & 15 & -0.046 & $<0.01$ \\
L +5 & 62 & 0.71 & $<0.01$ \\
\hline
\end{tabular}

* Physiological Stage: PP (4 to 0 weeks antepartum); L4 (0 to 4 weeks postpartum); L + 5 (5-14 weeks postpartum).

Singh et al. (2015) evaluated the effect of transitional period on BCS and RFT of crossbred cows during different phases (30 days prepartum, from 21 to 3 days prepartum, and from 3 to 30 days postpartum); they observed correlation coefficients equal to $r=0.84, r=0.79$, and $r=0.75$, respectively. For Holstein cows, Hussein et al. (2013) found strong correlations for animals between 1 and 3 weeks days prepartum $(\mathrm{r}=0.96)$ and from 15 to 18 weeks postpartum $(r=0.96)$. Yet for Zebu cows, Ayres et al. (2009) reported strong correlations for animals near calving $(r=0.93)$ and 11 weeks postpartum $(r=0.93)$.

According to Chagas et al. (2007), the correlation between BCS and body fat may be weaker at the lower end of the BCS scale, from which a sharp loss of BCS is enough to mobilize fat from muscle tissue, depleting the amount of subcutaneous adipose 
tissue. In a study conducted by Macdonald et al. The author attributed such a result to the broader (1999), the lowest correlations for these variables $(\mathrm{r}=0.26)$ were recorded in animals with $\mathrm{BCS}<4.5$ (10 points). These authors also noted that as RFT and BCS increased, correlations became stronger $(\mathrm{r}$ $=0.82$ ).

While assessing the relationship between RFT and BCS in Holstein and Nellore cows, Maciel (2006) found no correlations for Holstein cows, with BCS below 3.17. Furthermore, the largest correlation $(r=0.79)$ was observed for RFT between 2 and $7 \mathrm{~mm}$. This author also noted that the observed data amplitude also influenced the results, with the range of BCS in Zebu cows, as Holstein females with extreme BCS (very high nor very low) were disregarded, resulting in less data dispersion.

The value obtained for the coefficient of determination of the general regression was 0.33 . The significant models were those of groups PP and $\mathrm{L}+5(\mathrm{p}<0.05)$, where the determination coefficients were 0.61 and 0.51 respectively. Probably due to the constant metabolic changes in L4, BCS was ineffective in detecting the actual changes in adipose tissue mobilization, resulting in a $\mathrm{R}^{2}=$ 0.0021 . Figures $1,2,3$, and 4 represent the models. highest correlation coefficients for Holstein cows.

Figure 1. Linear regression between rump subcutaneous fat thickness on the back and body condition score of Dutch $\mathrm{x}$ Zebu crossbred cows during the transition period and early stages of lactation.

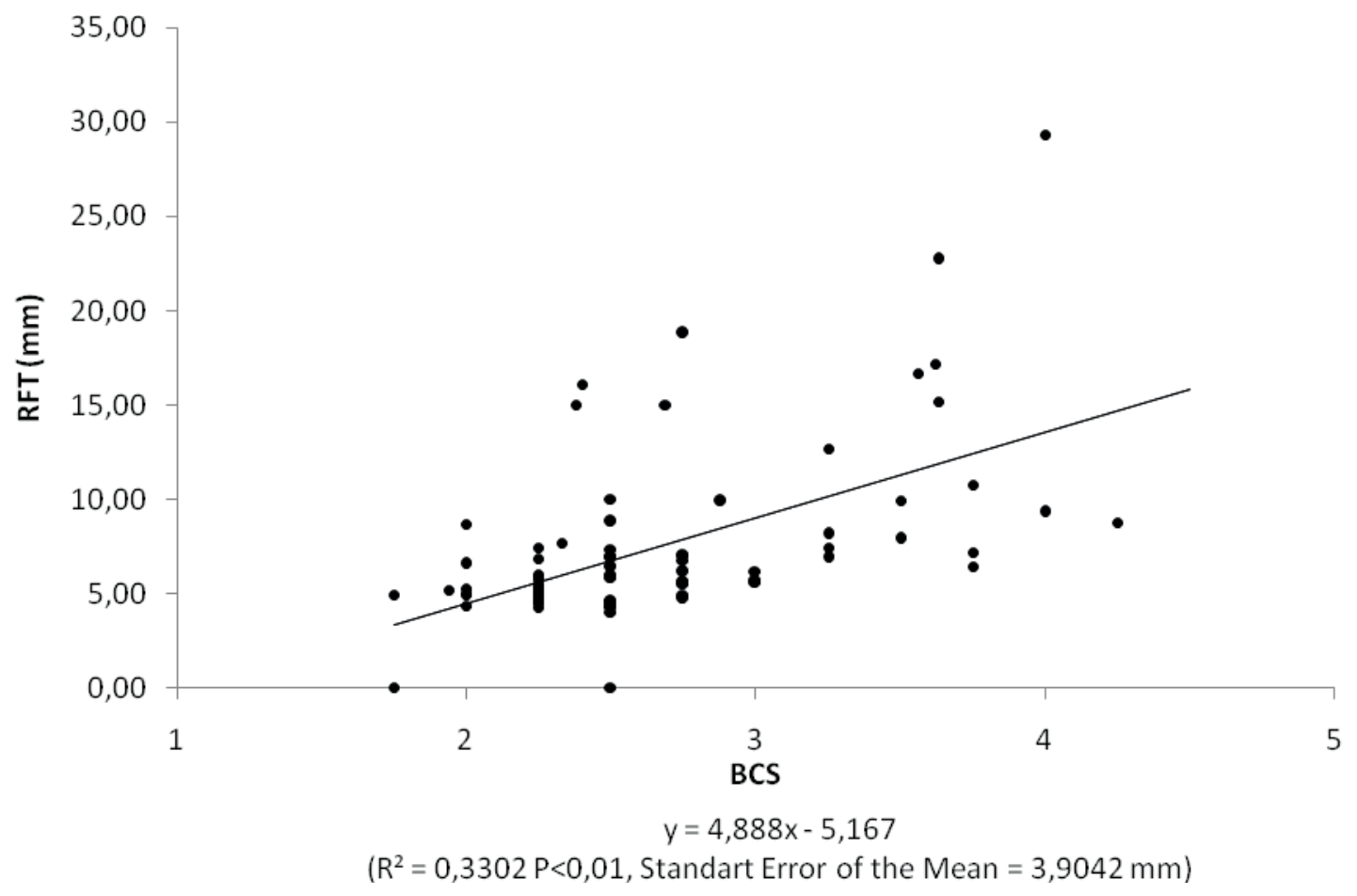


Figure 2. Linear regression between rump subcutaneous fat thickness on the back and body condition score of Dutch $\mathrm{x}$ Zebu crossbred cows during the period 4 to 0 weeks of childbirth.

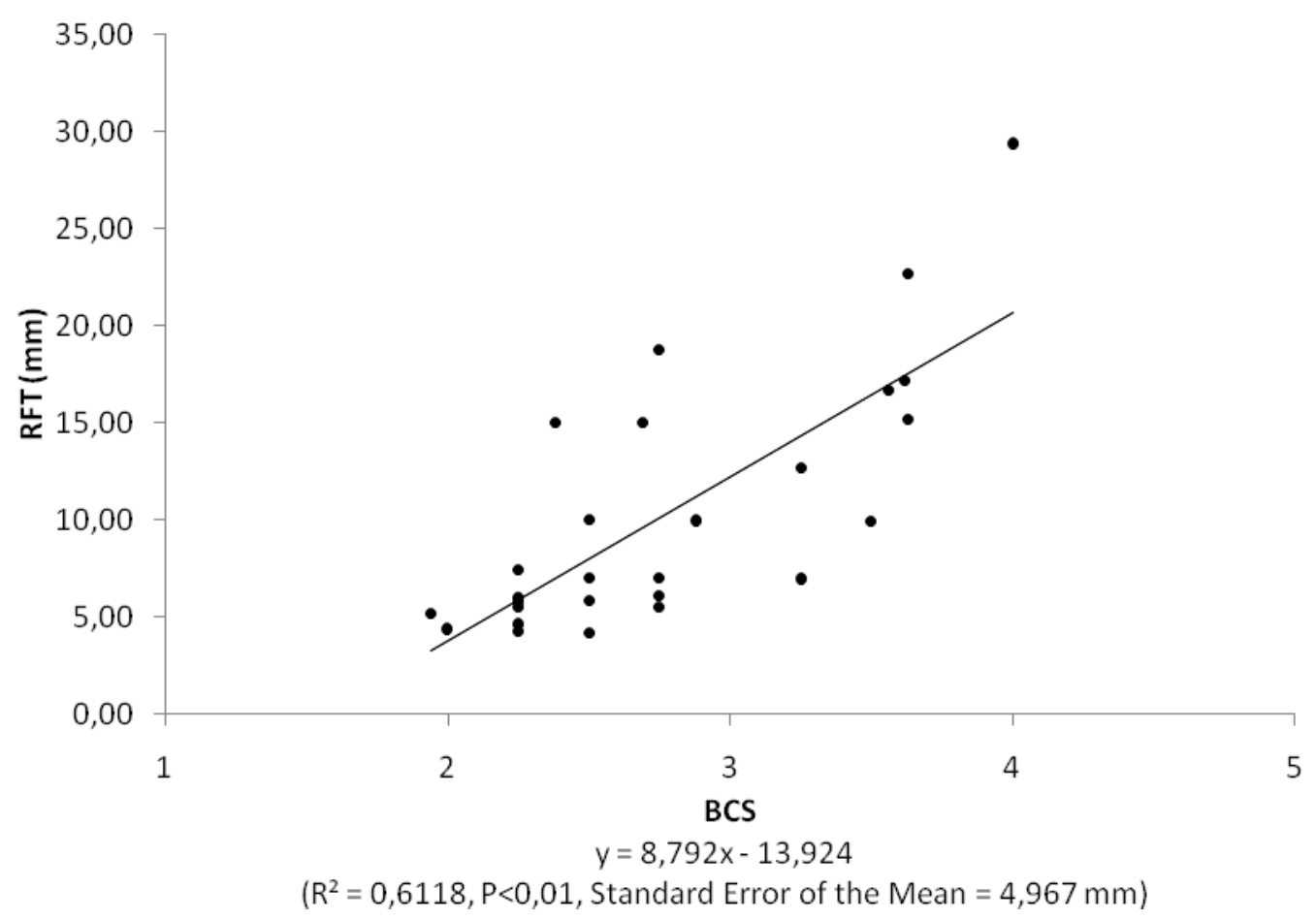

Figure 3. Linear regression between rump subcutaneous fat thickness on the back and body condition score of Dutch $\mathrm{x}$ Zebu crossbred cows during the period 4 to 0 weeks postpartum.

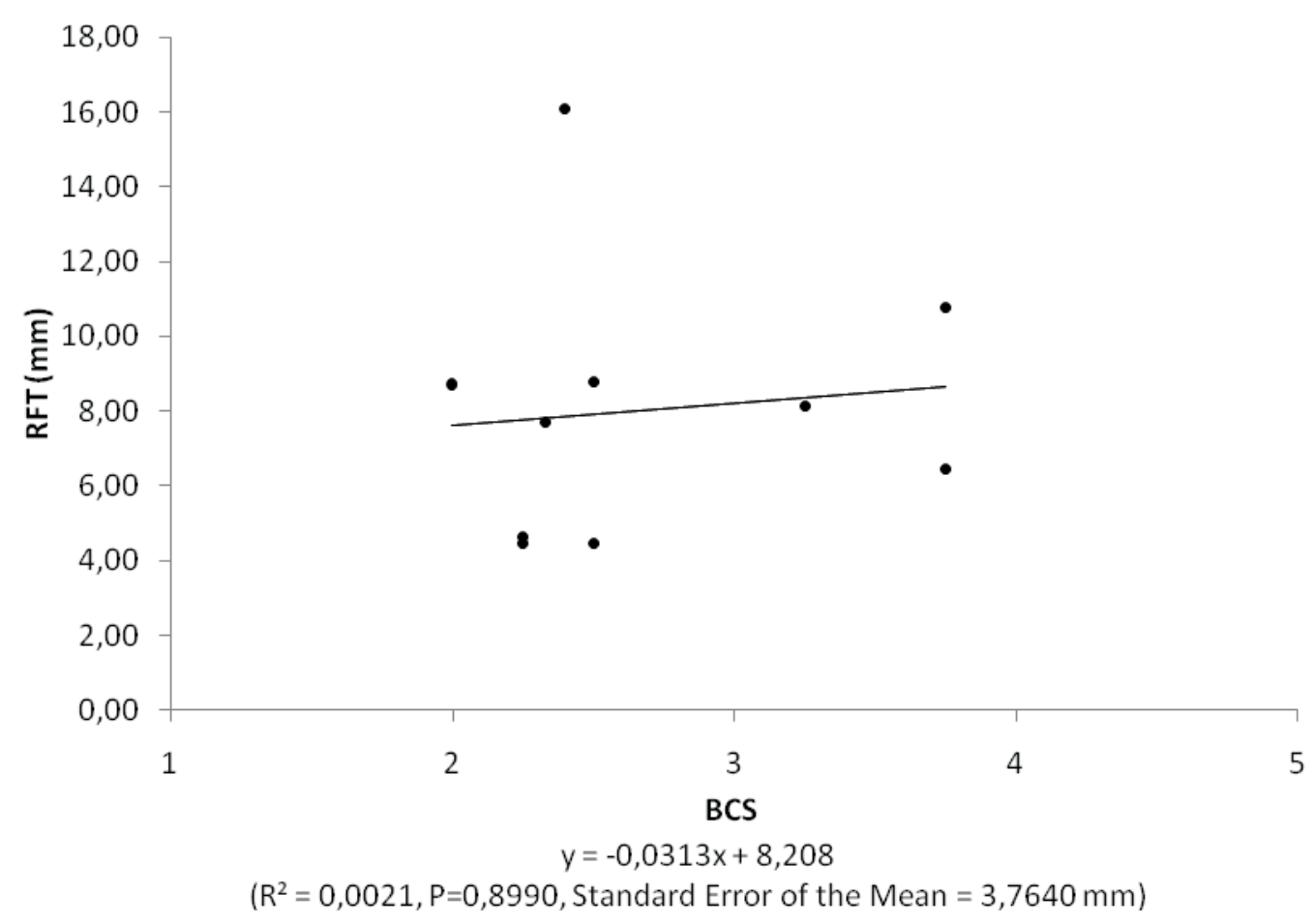


Figure 4. Linear Regression between rump subcutaneous fat thickness on the back and body condition score of Dutch $\mathrm{x}$ Zebu crossbred cows during the period from 5 to 14 weeks postpartum.

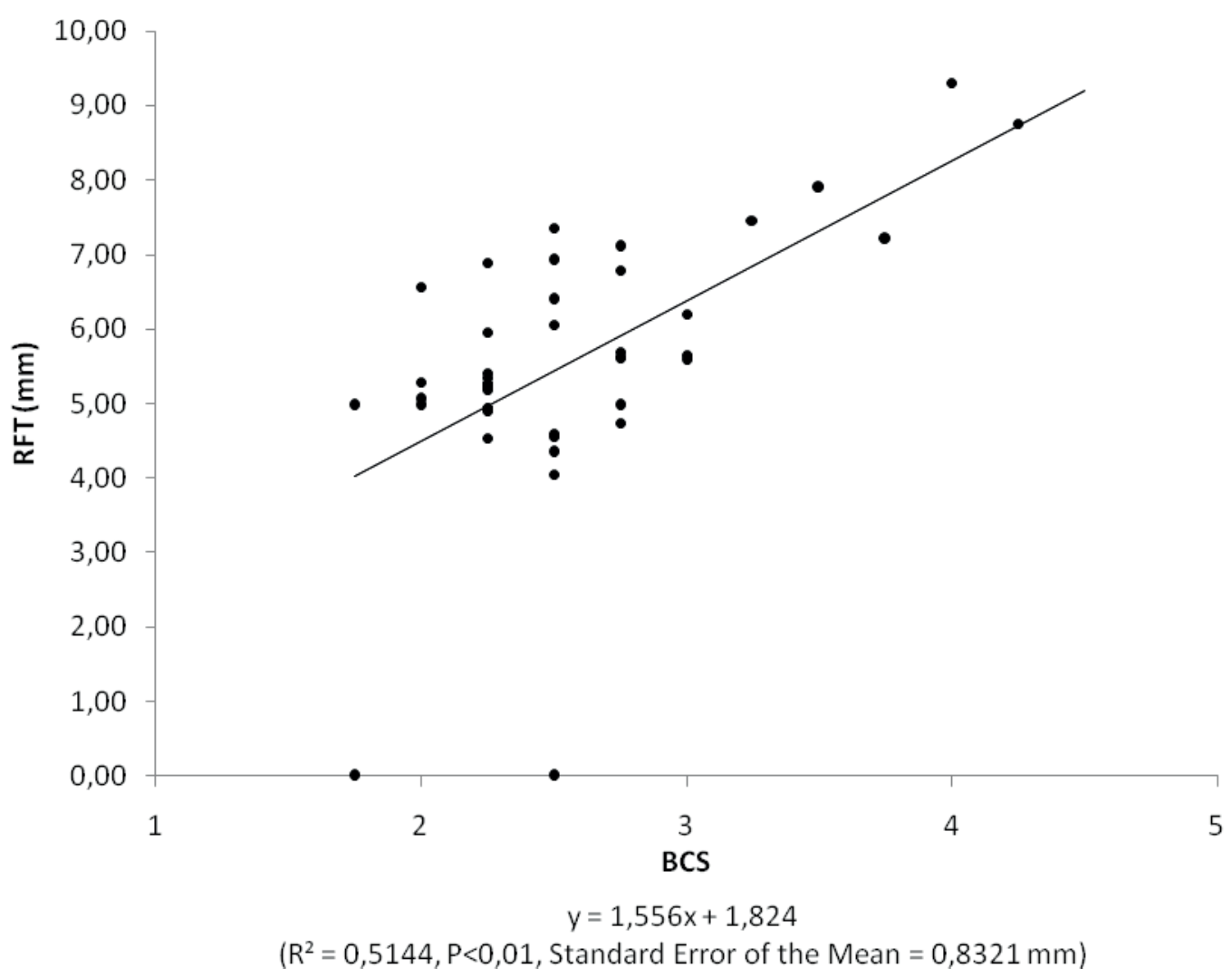

According to Figure 1, the two variables are related linearly during the transition period and early lactation. The regression models for PP and $\mathrm{L}+5$, the behavior of variables was similar to that in the general model; however, the coefficients of determination were higher, showing that the proposed models explain better the variation in RFT data. These results can be considered positive for the relationship between BCS and RFT measurements in crossbred animals, once Domecq et al. (1995) validated BCS with subcutaneous fat measurements using ultrasonography in some body parts of Holstein dairy cows, such as lower back, rump, and tail root. According to these authors, BCS was significantly associated with the ultrasound measurements of the rump, with a coefficient of determination of 0.65 . As a result, these authors concluded that ECC is as appropriate as ultrasound measurements to estimate subcutaneous fat in dairy cows.
The determination coefficients found here are smaller than are those reported in the literature, in studies with purebred animals. This finding might have occurred due to the varied breed groups of the assessed animals. For some authors, because it is a subjective method, BCS is easily influenced by factors such as breed or genetic merit, adipose tissue mobilization pattern, adipocyte size and age (PRYCE; HARRIS, 2006; WALSH et al., 2008).

\section{Conclusions}

The findings of this study indicate that if compared to Holstein purebreds, BCS is a good predictor of body condition for Holstein $\mathrm{x}$ Zebu crossbred cows, from the fourth week before calving until the fourteenth week postpartum. 


\section{References}

AYRES, H.; FERREIRA, R. M.; SOUZA TORRESJÚNIOR, J. R. de; DEMÉTRIO, C. G. B.; LIMA, C. G. de; BARUSELLI, P. S. Validation of body condition score as a predictor of subcutaneous fat in Nelore (Bos indicus) cows. Livestock Science, Amsterdam, v. 123, n. 2, p. 175-179, 2009.

CHAGAS, L.; BASS, J.; BLACHE, D.; BURKE, C.; KAY, J.; LINDSAY, D.; LUCY, M.; MARTIN, G.; MEIER, S.; RHODES, F. Invited review: New perspectives on the roles of nutrition and metabolic priorities in the subfertility of high-producing dairy cows. Journal of Dairy Science, Hamilton, v. 90, n. 9, p. 4022-4032, 2007.

CHILLIARD, Y.; CISSE, M.; LEFAIVRE, R.; REMOND, B. Body composition of dairy cows according to lactation stage, somatotropin treatment, and concentrate supplementation. Journal of Dairy Science, Dakar, v. 74, n. 9, p. 3103-3116, 1991.

DOMECQ, J.; SKIDMORE, A.; LLOYD, J.; KANEENE, J. Validation of body condition scores with ultrasound measurements of subcutaneous fat of dairy cows1. Journal of Dairy Science, Savoy, v. 78, n. 10, p. 23082313, 1995.

EDMONSON, A.; LEAN, I.; WEAVER, L.; FARVER, T.; WEBSTER, G. A body condition scoring chart for Holstein dairy cows. Journal of Dairy Science, Savoy, v. 72, n. 1, p. 68-78, 1989.

GOFF, J.; HORST, R. Physiological changes at parturition and their relationship to metabolic disorders1, 2. Journal of Dairy Science, Savoy, v. 80, n. 7, p. 1260-1268, 1997.

GRUMMER, R. R. Impact of changes in organic nutrient metabolism on feeding the transition dairy cow. Journal of Animal Science, Champaign, v. 73, n. 9, p. 2820-2833, 1995.

HUSSEIN, H.; WESTPHAL, A.; STAUFENBIEL, R. Relationship between body condition score and ultrasound measurement of backfat thickness in multiparous Holstein dairy cows at different production phases. Australian Veterinary Journal, St Leonards, v. 91, n. 5, p. 185-189, 2013.

HUZZEY, J.; VEIRA, D.; WEARY, D.; VON KEYSERLINGK, M. Prepartum behavior and dry matter intake identify dairy cows at risk for metritis. Journal of Dairy Science, Savoy, v. 90, n. 7, p. 3220-3233, 2007.

MACDONALD, K.; PENNO, J.; VERKERK, G. Validation of body condition scoring by using ultrasound measurements of subcutaneous fat. New Zealand Society of Animal Production, Hamilton, v. 59, p. 177-179, 1999.
MACIEL, A. B. de B. Proposta de avaliação da condição corporal em vacas holandesas e nelores. 2006. Dissertação (Mestrado em Ciências Agrárias e Veterinárias) - Universidade Estadual Paulista. Faculdade de Medicina Veterinária e Zootecnia.

MULLIGAN, F.; O'GRADY, L.; RICE, D.; DOHERTY, M. A herd health approach to dairy cow nutrition and production diseases of the transition cow. Animal Reproduction Science, Amsterdam, v. 96, n. 3, p. 331353, 2006.

NATIONAL RESEARCH COUNCIL - NRC. Nutrient requerements of dairy cattle. $7^{\text {th }}$. Washington: National Academies Press, 2001.

PRYCE, J.; HARRIS, B. Genetics of body condition score in New Zealand dairy cows. Journal of Dairy Science, Savoy, v. 89, n. 11, p. 4424-4432, 2006.

SCHRÖDER, U. J.; STAUFENBIEL, R. Invited review: Methods to determine body fat reserves in the dairy cow with special regard to ultrasonographic measurement of backfat thickness. Journal of Dairy Science, Savoy, v. 89, n. 1, p. 1-14, 2006.

SCHWAGER-SUTER, R.; STRICKER, C.; ERDIN, D.; KÜNZI, N. Relationship between body condition scores and ultrasound measurements of subcutaneous fat and $\mathrm{m}$. longissimus dorsi in dairy cows differing in size and type. Animal Science, Champaign, v. 71, n. 3, p. 465-470, 2000.

SHELDON, I. M.; LEWIS, G. S.; LEBLANC, S.; GILBERT, R. O. Defining postpartum uterine disease in cattle. Theriogenology, Milan, v. 65, n. 8, p. 1516-1530, 2006.

SINGH, R.; RANDHAWA, S.; RANDHAWA, C. Body condition score and its correlation with ultrasonographic back fat thickness in transition crossbred cows. Veterinary World, Wankaner, v. 8, n. 3, p. 290, 2015.

STATISTICAL ANALYSIS SYSTEMS INSTITUTE SAS. SAS user's guide: Statistics Version 2002. Cary: SAS, 2002.

STOUFFER, J.; CROSS, H. Evaluation of beef cattle with real time linear array ultrasound. Journal of Animal Science, Champaign, v. 61, p. 144, spl.1, 1985.

VARGAS JUNIOR, F. M. Efeito do grupo genético da progênie sobre a eficiência produtiva e reprodutiva de matrizes nelores. 2003. Tese (Doutorado na área Nutrição e Produção Animal). Faculdade de Medicina Veterinária e Zootecnia. Universidade Estadual Paulista, Botucatu.

WALSH, S.; BUCKLEY, F.; PIERCE, K.; BYRNE, N.; PATTON, J.; DILLON, P. Effects of breed and feeding system on milk production, body weight, body condition 
score, reproductive performance, and postpartum ovarian function. Journal of Dairy Science, Savoy, v. 91, n. 11, p. 4401-4413, 2008.

WEBER, C.; HAMETNER, C.; TUCHSCHERER, A.; LOSAND, B.; KANITZ, E.; OTTEN, W.; SINGH, S.; BRUCKMAIER, R.; BECKER, F.; KANITZ, W. Variation in fat mobilization during early lactation differently affects feed intake, body condition, and lipid and glucose metabolism in high-yielding dairy cows. Journal of Dairy Science, Savoy, v. 96, n. 1, p. 165-180, 2013.

WILDMAN, E.; JONES, G.; WAGNER, P.; BOMAN, R.; TROUTT, H.; LESCH, T. A dairy cow body condition scoring system and its relationship to selected production characteristics. Journal of Dairy Science, Savoy, v. 65, n. 3, p. 495-501, 1982. 